\title{
Drivers of clutch-size in Fork-tailed Flycatchers (Tyrannus savana) at temperate and tropical latitudes in South America
}

\author{
Alex E. Jahn ${ }^{\mathrm{A}, \mathrm{E}}$, Diego T. Tuero ${ }^{\mathrm{B}}$, Ana Maria Mamani ${ }^{\mathrm{C}}$, Vanesa Bejarano ${ }^{\mathrm{C}}$, \\ Diego Anibal Masson ${ }^{\mathrm{D}}$ and Eluney Aguilar ${ }^{\mathrm{D}}$ \\ ADepartamento de Zoologia, Universidade Estadual Paulista - Rio Claro, Avenida 24a 1515, \\ CEP 13506-900, Rio Claro, São Paulo, Brazil. \\ ${ }^{B}$ Departamento de Ecología, Genética y Evolución, Universidad de Buenos Aires e Instituto de Ecología, \\ Genética y Evolución de Buenos Aires (IEGEBA), Consejo Nacional de Investigaciones Científicas y Técnicas \\ (CONICET), Int. Güiraldes 2160 - Pabellón II, Ciudad Universitaria, C1428EHA, Buenos Aires, Argentina. \\ ${ }^{C}$ Museo de Historia Natural Noel Kempff Mercado, Avenida Irala 565, Santa Cruz de la Sierra, Bolivia. \\ D Facultad de Ciencias Naturales y Museo, Universidad Nacional de La Plata, B1904CCA, \\ Avenida 122 y 60, La Plata, Buenos Aires, Argentina. \\ ${ }^{\mathrm{E} C o r r e s p o n d i n g ~ a u t h o r . ~ E m a i l: ~ a j a h n @ r c . u n e s p . b r ~}$
}

\begin{abstract}
Many species of birds exhibit a latitudinal gradient in annual reproductive investment, laying more eggs and producing more nestlings at higher latitudes. However, few studies have evaluated the mechanisms that underlie such patterns and such differences in grassland birds specifically. We monitored nests of Fork-tailed Flycatchers (Tyrannus savana) over two breeding seasons at a tropical site in Bolivia (in 2010-11 and 2011-12) and three breeding seasons at a southern temperate site in Argentina (2010-11, 2011-12 and 2012-13), testing two hypotheses explaining variation in clutch-size among populations: the food-limitation hypothesis and the nest-predation hypothesis. Mean clutch-size and mean brood-size were significantly larger at the temperate study site than at the tropical site. Availability of arthropod food per individual bird was significantly higher at the temperate site. There was no relationship, positive or negative, between rates of nest predation and either clutch- or brood-size, and thus no support for the nest-predation hypothesis. We conclude that food availability explains much of the latitudinal variation in clutch-size in this species. We discuss avenues for future research on the mechanisms underlying geographical variation in the life histories of Neotropical birds.
\end{abstract}

Received 26 August 2013, accepted 9 June 2014, published online 15 September 2014

\section{Introduction}

Variation in reproductive investment among bird populations has been a subject of intense research for decades (e.g. Skutch 1949; Snow 1978; Ricklefs 1970, 1980; Martin 1996; Robinson et al. 2010; Rose and Lyon 2013). Such research has shown that passerine birds at tropical and southern temperate latitudes generally lay smaller clutches than populations breeding at northern temperate latitudes (Yom-Tov et al. 1994; Martin et al. 2000; Auer et al. 2007; reviews by Martin 1996, Jetz et al. 2008).

Although various hypotheses have been proposed to explain such latitudinal differences in clutch-size, the underlying causes of this variation are still not well understood (Ricklefs and Wikelski 2002). Hesse et al. (1937) and Lack (1947) suggested that, in altricial birds, larger clutch-sizes result from increased foraging time afforded by longer daylength at higher latitudes. Skutch (1949) proposed that high rates of nest predation at tropical latitudes may select for smaller clutch-sizes because smaller clutches allow fewer feeding visits by parents and produce less noisy broods (Slagsvold 1982), reducing the likelihood of a predator finding the nest by observing the parents or hearing the nestlings; this is the nest-predation hypothesis. Smaller clutches also minimise wasted parental effort when eggs or nestlings are depredated (Slagsvold 1982). Lack (1954) and later von Haartman (1971) asserted that greater availability of food during the breeding season at higher latitudes would lead to increased clutch-size - the food-limitation hypothesis - and Ashmole (1963) suggested that clutch-size depends on the level of food availability per individual bird during the breeding season relative to the non-breeding season. A more recent explanation posits that an increased risk of adult predation leads to less time spent by adults foraging, and thus less time exposed to predators, resulting in smaller clutch-sizes (Lima 1987, 2009).

Given the wide variation in life-history strategies (e.g. neststructure and habitat), diet and latitudinal range limits in the Tyrannidae (Fitzpatrick 2004), tests of hypotheses on geographical variation in reproductive investment within this family could yield novel insights into the multiple factors moulding avian reproductive strategies. In particular, the Fork-tailed Flycatcher (Tyrannus savana) is an ideal candidate to study intraspecific latitudinal variation in reproductive investment because the species is widespread, breeding from Mexico to southern South America, and is reasonably common throughout its range 
(Teul et al. 2007; Jahn and Tuero 2013; Mobley 2013). The nominate subspecies breeds at tropical latitudes in central South America south to the temperate latitudes of central Argentina Ridgely and Tudor 1994).

Here we provide one of the first tests of hypotheses on latitudinal variation in avian clutch-size between southern temperate and tropical latitudes in the New World. Most previous studies evaluating variation in clutch-size have compared patterns across species (Martin et al. 2000; Auer et al. 2007; but see Mattsson et al. 2011; Rose and Lyon 2013), whereas intraspecific comparisons are more pertinent to elucidating the mechanisms underlying selection for a given strategy (Gustafsson and Sutherland 1988).

We compare measures of reproductive investment (clutchsize and brood-size) and success (rates of nest survival and the number of fledglings per nest) of Fork-tailed Flycatchers, and the abundance of nest predators, at tropical and temperate latitudes of South America. We test two hypotheses on variation in clutch-size: (1) the nest-predation hypothesis (Skutch 1949; Snow 1962, 1978; Slagsvold 1982), by testing the prediction that the size of clutches and broods exhibit a positive relationship with rates of nest predation; and (2) the food-limitation hypothesis (Lack 1954; von Haartman 1971) by testing the prediction that smaller clutches are found at the site with lower availability of food per bird.

\section{Materials and methods}

\section{Study sites}

Our tropical latitude study site was in the Parque Regional Lomas de Arena, Santa Cruz Department, Bolivia $\left(17^{\circ} 54^{\prime} 7^{\prime \prime} \mathrm{S}\right.$, $\left.63^{\circ} 10^{\prime} 26^{\prime \prime} \mathrm{W}\right)$. The vegetation of this site is primarily grassland with scattered trees, mainly Acacia albicorticata; parts of the grassland are degraded by grazing of livestock and scattered human habitation, at the edge of the town of Santa Cruz de la Sierra. At this site we monitored nests during two breeding seasons, over an area of 138.3 ha in September-January 2010-11 and 135.6 ha in September-January 2011-12. Our temperate latitude study site was in the Reserva Privada El Destino, Province of Buenos Aires, Argentina $\left(35^{\circ} 8^{\prime} 24^{\prime \prime} \mathrm{S}\right.$, $\left.57^{\circ} 23^{\prime} 38^{\prime \prime} \mathrm{W}\right)$. The vegetation is primarily temperate grassland and marshes grazed by cattle, and intersected by woodland tracts dominated by Tala (Celtis ehrenbergiana) and Coronillo (Scutia buxifolia). We monitored nests at this site over an area of 777.7 ha in October-January over 3 breeding seasons (2010-11, 2011-12, 2012-13).

\section{Monitoring of nests}

We searched for nests throughout the breeding season, which we treated as starting when Flycatchers were seen carrying nesting material or defending a territory. Because clutch-size could be strongly affected by laying date (Stutchbury and Roberston 1988; Winkler and Allen 1996), we monitored nests throughout the breeding season at each site. Nesting took place SeptemberJanuary at the tropical site in Bolivia, and October-January at the temperate site in Argentina. When a nest was found, its location was determined (using GPSmap 76, Garmin International, Inc., Olathe, KS, USA, accuracy $<10 \mathrm{~m}$ ) and monitored following standard protocols (Ralph et al. 1993). Specifically, each nest was checked every 3 to 4 days (more frequently close to when hatching or fledging was expected), using a mirror on a pole to inspect the nest contents, which were noted, along with time and date. A nest was considered to have a completed clutch when it had the same number of eggs after two consecutive checks of nest contents (i.e., the female had finished laying). To maintain statistical independence, we excluded re-nesting attempts within the same season and, where we had more than 1 year of data from the same territory, we used the average clutch- and broodsize among years because the same pairs of birds often used the same territory between years (A. E. Jahn, unpubl. data). Abandoned nests were defined as those in which eggs were present but there was no parental activity evident for several days, or eggs were cold after the laying period finished. A nest was considered depredated when the nest had contained eggs or nestlings not yet ready to fledge and was subsequently found empty. In these cases, eggshells were often found inside or beneath the nest. A nest was considered successful when at least one nestling fledged. In some cases, we were not able to record the fate of a nest because of logistical or time constraints, in which case we classified the result as unknown.

\section{Abundance of nest predators}

Although mammals and reptiles could depredate Fork-tailed Flycatcher nests, birds are likely to be the primary nest predators at our study sites because Flycatcher nests are generally found closer to the outside of the tree (A. E. Jahn and D. T. Tuero, pers. obs.) and so more accessible to avian predators rather than terrestrial predators. Previous research in Argentina and elsewhere in the southern hemisphere has found birds to be the main predators of nests (reviewed by Martin et al. 2000). The only documented predators of Fork-tailed Flycatcher nests in South America are the Guira Cuckoo (Guira guira) and Chimango Caracara (Milvago chimango) (Salvador 2013). We considered these two species, as well as other raptors, such as Roadside Hawks (Rupornis magnirostris) and Southern Caracaras (Caracara plancus), and birds known to depredate nests generally, such as Toco Toucans (Ramphastos toco), to be predators of Flycatcher nests. We estimated predator species richness and the abundance of these species along transects that included Flycatcher territories at each study site (transect $3 \mathrm{~km}$ long at the tropical study site in Bolivia, $1 \mathrm{~km}$ long in the southern temperate site in Argentina). Counts were conducted by a single person (A. M. Mamani in Bolivia, D. Masson in Argentina) walking at $1.5 \mathrm{~km} \mathrm{~h}^{-1}$ along the transect; counts were done between sunrise and 1100 hours in the 2010-11 and 2011-12 breeding seasons, and all birds seen or heard at any distance were recorded. At the tropical site in Bolivia, four counts were conducted 9 September-13 October 2010 and five 8 September27 October 2011. At the temperate site in Argentina, six counts were conducted 2 November 2010-6 January 2011 and five 4 November 2011-3 January 2012.

\section{Sampling of arthropods}

Like many other New World flycatchers, Fork-tailed Flycatchers are primarily insectivorous, taking arthropods by sallying or by gleaning from leaves or the ground (Ridgely and Tudor 1994; Restall et al. 2006; Jahn and Tuero 2013; Mobley 2013). We 
considered the arthropod food for Flycatchers to be those orders of insects that we observed them eating (Diptera, Hymenoptera, Odonata and Isoptera) or which have been observed in the diet of a congener at similar latitudes: Tropical Kingbirds (Tyrannus melancholicus) have been observed eating (Coleoptera, Homoptera, Hymenoptera, Lepidoptera, Odonata and Orthoptera (Jahn et al. 2010).

Arthropods were sampled during the 2010-11 breeding season at each site. In Bolivia, sampling was conducted every 6-8 days from 6 October 2010 to 26 January $2011 \quad(n=17$ samples). In Argentina, sampling was conducted every 3-12 days from 2 November 2010 to 6 January 2011 ( $n=13$ samples). Sampling was done by sweeping, at 2 sweeps s$^{-1}$, an insect net (46-cm diameter, $91.5 \mathrm{~cm}$-long handle; Bioquip insect net, Bioquip Products Inc., Rancho Dominguez, CA, USA) across the top of shrubs and grasses (where Flycatchers commonly forage on arthropods; A. E. Jahn and D. T. Tuero, pers. obs.) for $1 \mathrm{~h}$ between 0800 and 1100 hours on a $1-\mathrm{km}$ transect that traversed nesting territories of Flycatchers. After every 100 sweeps of the net, arthropods were transferred from the net to a plastic jar that contained $70 \%$ ethanol. At the end of each sampling traverse, arthropods were transferred from the jar to a sealed bag (Nasco Whirl-Pak sample bags, Nasco, Fort Atkinson, WI, USA) with $70 \%$ ethanol, where they were stored until analysed. Arthropods were identified using a dissecting microscope, and the number of arthropods of each order for each sampling traverse recorded. Arthropods collected in Bolivia are stored at the Museo de Historia Natural Noel Kempff Mercado (Santa Cruz de la Sierra, Bolivia).

\section{Density of breeding pairs}

We estimated the density of breeding pairs of Flycatchers by first plotting a polygon encompassing all the nests we monitored at each study site in Google Earth (Google, Mountain View, CA, USA). We then performed coordinate system transformation and calculation of the area within the polygons using the XTools 9.1 extension for ArcGIS 10.1 (Environmental Systems Research Institute, Redlands, CA, USA).We then determined the number of breeding pairs per hectare (there is one pair at each nest) by dividing the number of nests found in each study site in each breeding season by the area of the study sites. Throughout, we report values (except percentages) as means \pm standard error. We compared nest predation rates using a one-tailed $\mathrm{Z}$ test for two proportions (see www.socscistatistics.com/tests/ztest, accessed 21 May 2014). We compared clutch and brood sizes using two sample t-tests using program Statistica version 8.0 (StatSoft Inc., Tulsa, OK, USA), and a Kruskal-Wallis rank sum test to compare arthropod food availability and predator abundances using program R version 3.0.1 (R Core Team 2013).

\section{Results}

At the tropical study site in Bolivia, we monitored 28 nests in the 2010-11 breeding season and 39 in the 2011-12 season. At the southern temperate study site in Argentina, we monitored 27 nests in the 2010-11 breeding season, 41 in 2011-12 and 34 in 2012-13. Clutch-size was larger in the southern temperate site (Argentina) than in the tropical site (Bolivia) in both the 2010-11 and 2011-12 breeding seasons (Fig. 1). Of complete clutches,

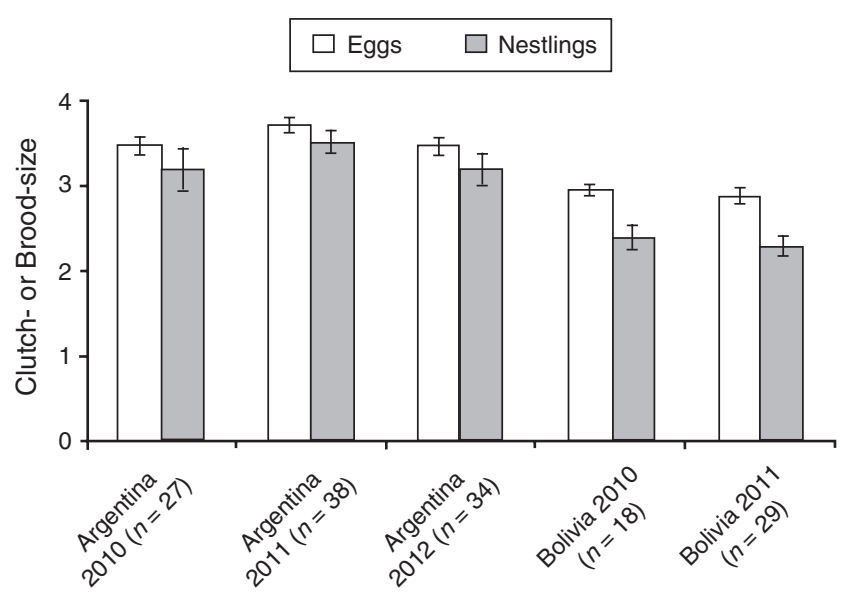

Fig. 1. Mean clutch- and brood-sizes of Fork-tailed Flycatchers for each year and study site: the southern temperate site at Reserva Privada El Destino, Province of Buenos Aires, Argentina; and the tropical site at Parque Regional Lomas de Arena, Santa Cruz Department, Bolivia. Error bars represent standard error.

only $4 \%$ ( 2 of 47 ) in Bolivia were of more than three eggs, whereas $58 \%$ (57 of 99) in Argentina were of more than three eggs. Overall, clutch-size was significantly larger in Argentina (3.5 $\pm 0.06, n=64)$ than in Bolivia $(2.9 \pm 0.06, n=35 ; t=6.38$, d.f. $=97, P<0.0001$ ), as was brood size (Argentina: $3.3 \pm 0.12$, $n=44$; Bolivia: $2.3 \pm 0.10, n=34 ; t=5.72$, d.f. $=76, P<0.0001$; this comparison uses average size of clutches and broods among years when there were data for more than 1 year from the same territory; see Methods).

Of 79 nests in Argentina of known fate (either known to have failed or successfully fledged at least one young; fate of 23 nests not known), 47\% $(n=37)$ were successful, $45 \%(n=36)$ were depredated, $4 \%(n=3)$ were abandoned by the parents, $3 \%(n=2)$ had nestlings die owing to parasitism by Philornis fly larvae, and $1 \%(n=1)$ failed owing to parasitism by Shiny Cowbirds (Molothrus bonariensis). Of 44 nests of known fate in Bolivia (fate of 23 not known), 52\% $(n=23)$ were successful, 29\% $(n=13)$ were depredated, $5 \%(n=2)$ were destroyed by wind, $5 \%(n=2)$ were abandoned, $2 \%(n=1)$ failed owing to people cutting down the nest-tree, and $7 \%(n=3)$ failed owing to unknown causes.

Rates of nest predation at each site were highest for clutches of three (Table 1). Combining data across both sites, there was no significant difference in the rate of predation of nests with smaller clutches (2-3 eggs) compared with larger clutches (4-5 eggs; onetailed $Z$ test for two proportions: $Z=1.40, P=0.081$ ).

In Argentina, the rate of nest predation was higher for broods of three and four than broods of at one or two (Table 1), although one nest with a brood of five was successful. In Bolivia, the rate of nest predation was similar for broods of two and three and higher for these brood-sizes than for broods of one, although low sample sizes precluded statistical analysis (Table 1). Across both sites, the rate of nest predation decreased fivefold from a brood of one to a brood of two, and was higher at brood-sizes of three or four compared to a brood size of two (Table 1), with no significant difference in the predation rate of nests with smaller broods (1-2) compared with larger broods (3-5; $Z=-0.21, P=0.417)$. 
Table 1. Total number of nests of known outcome (either fledged or depredated), and number and percentage of nests depredated (predation rate) for each size of clutch or brood at study sites in Argentina (southern temperate) and Bolivia (tropical)

\begin{tabular}{lrcrcrr}
\hline & \multicolumn{2}{c}{ Argentina } & \multicolumn{2}{c}{ Bolivia } & \multicolumn{2}{c}{ Overall } \\
\multicolumn{2}{c}{ Total nests } & Depredated & Total nests & Depredated & Total nests & Depredated \\
\hline Clutch-size & & & & & & \\
2 & 2 & $1(50 \%)$ & 3 & $1(33 \%)$ & 5 & $2(40 \%)$ \\
3 & 26 & $17(65 \%)$ & 24 & $10(42 \%)$ & 50 & $27(54 \%)$ \\
4 & 42 & $17(40 \%)$ & 1 & 0 & 43 & $17(40 \%)$ \\
5 & 1 & 0 & 0 & - & 1 & 0 \\
Brood-size & & & & & & \\
1 & 1 & $0(0 \%)$ & 4 & $3(75 \%)$ & 5 & $3(60 \%)$ \\
2 & 4 & $0(0 \%)$ & 13 & $2(15 \%)$ & 17 & $2(12 \%)$ \\
3 & 15 & $5(33 \%)$ & 12 & $2(17 \%)$ & 27 & $7(26 \%)$ \\
4 & 24 & $6(25 \%)$ & 0 & - & 24 & $6(25 \%)$ \\
5 & 1 & $0(0 \%)$ & 0 & - & 1 & 0 \\
\hline
\end{tabular}

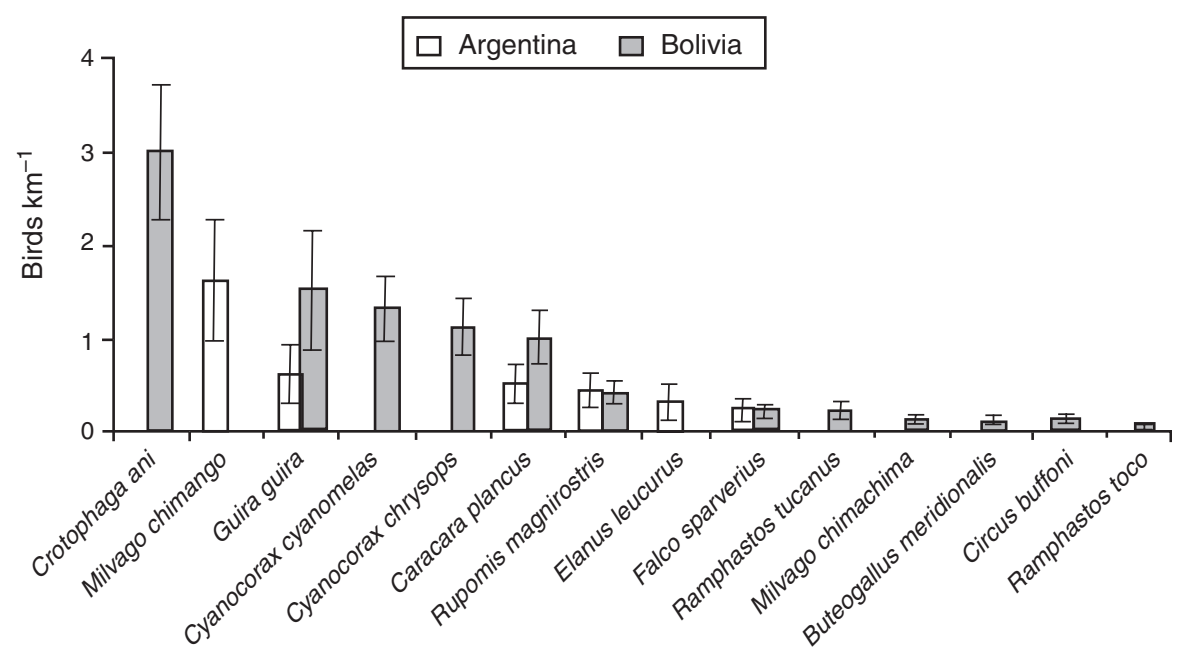

Fig. 2. Mean abundance of avian nest predators at each study site: the southern temperate site at Reserva Privada El Destino, Province of Buenos Aires, Argentina; and the tropical site at Parque Regional Lomas de Arena, Santa Cruz Department, Bolivia. Error bars represent standard error.

In Argentina, the arthropod orders known to be or possibly in the diet of Fork-tailed Flycatchers that we collected were Coleoptera, Diptera, Hymenoptera, Lepidoptera, Odonata and Orthoptera. In Bolivia, the same orders were collected, as well as Homoptera. The abundance of arthropod food was higher in Argentina (374.0 \pm 94.5 arthropods/sample) than in Bolivia $\left(15.2 \pm 2.3 ; \chi^{2}=21.42\right.$, d.f. $\left.=1, P<0.0001\right)$. The density of breeding pairs of flycatchers in Argentina was 0.03 pairs ha ${ }^{-1}$ in 2010-11, 0.05 pairs ha ${ }^{-1}$ in 2011-12 and 0.04 pairs $^{-1}$ in 2012-13; in Bolivia, density was 0.2 pairs ha $^{-1}$ in 2010-11 and 0.3 pairs ha $^{-1}$ in 2011-12.

We recorded a total of six species of potential nest predators at the Argentinian study site (in descending order of abundance): Chimango Caracara, Guira Cuckoo, Southern Caracara, Roadside Hawk, White-tailed Kite (Elanus leucurus) and American Kestrel (Falco sparverius). In Bolivia, we recorded 12 species of potential nest predators, the most common being Smoothbilled Ani (Crotophaga ani), Guira Cuckoo, Purplish Jay
(Cyanocorax cyanomelas), Plush-crested Jay (Cyanocorax chrysops) and Southern Caracara (Fig. 2). Overall, the abundance of potential nest predators was significantly lower at the southern temperate site in Argentina (3.5 \pm 1.19 predators $\left.\mathrm{km}^{-1}\right)$ than in the northern tropical site in Bolivia $\left(9.7 \pm 0.94 ; \chi^{2}=8.20\right.$, d.f. $=1$, $P=0.004)$.

\section{Discussion}

We found that Fork-tailed Flycatchers had significantly larger clutches and broods at the southern temperate site than at the tropical site in South America. Our results support the foodlimitation hypothesis explanation for latitudinal variation in clutch-size, with the temperate site with larger clutch-sizes, in Argentina, having significantly more arthropod food available but a lower density of breeding pairs of Fork-tailed Flycatchers compared with the site with smaller clutch-sizes in Bolivia. Overall, there was no clear relationship between rates of nest 
predation and clutch- or brood-size, which does not support the nest-predation hypothesis.

The clutch-sizes we report are similar to those of other studies of this species at similar latitudes, and corroborate the general pattern of larger clutch-sizes at temperate latitudes relative to tropical latitudes across bird species (reviewed by Jetz et al. 2008). At latitudes similar to that of our tropical study site $\left(18^{\circ} \mathrm{S}\right)$, mean clutch-size of Fork-tailed Flycatchers was $2.5 \pm 0.3$ (s.e.) eggs at $16^{\circ} \mathrm{S}$ in central Brazil (Marini et al. 2009) and 2.6 at $17^{\circ} \mathrm{N}$ in Belize (Teul et al. 2007) compared with $2.9 \pm 0.06$ in our study. In contrast, at higher latitudes similar to those of our temperate study site $\left(35^{\circ} \mathrm{S}\right)$, mean clutch-size was $3.3 \pm 0.3$ (s.e.) at $34^{\circ} \mathrm{S}$ in Argentina (Mezquida 2002) and $3.8 \pm 0.63$ (s.d.) at $32^{\circ} \mathrm{S}$, also in Argentina (Salvador 2013), compared with $3.5 \pm 0.06$ eggs of our study.

The rate of nest failure at a study site in central Brazil $\left(16^{\circ} \mathrm{S}\right.$; Marini et al. 2009) was the same as that found in our tropical study site in Bolivia ( $48 \%$ in both studies), although the proportion of nests that failed owing to predation in the Brazilian study (44\%) was higher than recorded by us in Bolivia (29\%). The rate of nest predation (36\%) in Belize (Teul et al. 2007) was closer to that in Bolivia in our study. The studies of Mezquida (2002) and Salvador (2013) in Argentina at similar latitudes to those of our temperate study site did not report rates of next predation rate.

The higher rates of nest predation at our temperate site relative to our tropical site contradicts previous research suggesting that tropical birds generally experience higher rates of nest predation than temperate species (reviewed by Martin 1996). Our results corroborate more recent studies showing substantial overlap in rates of nest predation across latitudes (e.g. Robinson et al. 2000) and contradict studies on other species in which clutchsize is inversely related to the rate of nest-predation (e.g. Cassey et al. 2009) or which suggest a minimal role of food limitation (Ferretti et al. 2005). Our results are more similar to those of Samaš et al. (2013), who reported smaller clutch-sizes in New Zealand than in Europe, in spite of lower rates of nest predation in New Zealand.

Future research should consider additional explanations for latitudinal variation in the reproductive investment of Forktailed Flycatchers. For example, Fork-tailed Flycatchers breeding at southern temperate latitudes weigh more than those breeding at tropical latitudes (A. E. Jahn, unpubl. data), which could allow them to lay larger clutches. Also, those breeding at tropical latitudes migrate shorter distances than temperate breeders, which are long-distance migrants (Jahn et al. 2013). If, as a result, tropical breeders experience fewer risks during migration and have higher individual adult survival rates, the lower clutchsizes at tropical latitudes could result from a trade-off between longevity and reproduction (Roff 1992; Samaš et al. 2013).

Additional explanations may also exist, such as perceived predation risk, which may limit access to food and therefore result in smaller clutches, even where food is not limited (Zanette et al. 2013). Moreover, the daylength hypothesis (Hesse et al. 1937; Lack 1947), which has been found to explain latitudinal variation in clutch-size in North American swallows (Rose and Lyon 2013), could be teased apart from those tested here by studying multiple, nest-specific parameters, such as the daily number of trips to the nest by parents to feed nestlings, the size of food items delivered to the nest (Martin et al. 2000, Rose and Lyon 2013), and rates of nest predation for specific predators. Indeed, although the abundance of potential nest predators was higher in Bolivia than Argentina, rates of nest predation were higher in Argentina, suggesting that some avian nest predators in Argentina disproportionately contribute to depredation of Flycatcher nests. Additionally, the contribution of nest predation by mammals and reptiles remains unknown, yet may help to account for the higher overall rate of nest predation we observed in Argentina.

Understanding the trade-offs that drive geographical variation in reproductive investment by birds at a finer spatial scale and among multiple years could yield novel insights into life-history theory generally and a better grasp of the risks different avian populations face across the planet.

\section{Acknowledgements}

We thank two anonymous reviewers and the Associate Editor for helpful comments, which greatly improved the manuscript. We are grateful to V. Cueto, the Fundación Elsa Shaw de Pearson, Parque Regional Lomas de Arena, and Reserva Privada El Destino for logistical support. A. Alcoba, O. Barroso, N. Bogado, I. García, J. Pinto Ledezma, M. J. Ledezma, Z. Pérez, M. Saldias, D. Salvatierra, V. Sandoval, Q. Vidoz and E. Williams provided invaluable assistance. This research was funded through two National Geographic Society Scientific Research Grants (numbers 8444-08 and 8953-11), a National Science Foundation International Research Fellowship to A. E. Jahn (IRFP-0965213), the Gatorade Fund of the University of Florida, Optics for the Tropics, and the Consejo Nacional de Investigaciones Científicas y Técnicas (CONICET), Argentina. A. E. Jahn thanks the Fundação de Amparo à Pesquisa do Estado de São Paulo (\#2012/17225-2) for support during data analysis and writing of the manuscript. This research was conducted with the authorisation of the Departamento de Flora y Fauna, Ministerio de Asuntos Agrarios, Provincia de Buenos Aires, Argentina (Disposición 256/11), and of the Dirección General de Biodiversidad of Bolivia.

\section{References}

Ashmole, N. P. (1963). The regulation of numbers of tropical oceanic birds. Ibis 103b, 458-473. doi:10.1111/j.1474-919X.1963.tb06766.x

Auer, S. K., Bassar, R. D., Fontaine, J. J., and Martin, T. E. (2007). Breeding biology of passerines in a subtropical montane forest in northwestern Argentina. Condor 109, 321-333. doi:10.1650/0010-5422(2007)109 [321:BBOPIA]2.0.CO;2

Cassey, P., Boulton, R. L., Ewen, J. G., and Hauber, M. E. (2009). Reduced clutch-size is correlated with increased nest predation in exotic Turdus thrushes. Ети 109, 294-299. doi:10.1071/MU09017

Ferretti, V., Llambías, P. E., and Martin, T. E. (2005). Life-history variation of a neotropical thrush challenges food limitation theory. Proceedings of the Royal Society of London - B. Biological Sciences 272, 769-773. doi:10.1098/rspb.2004.3039

Fitzpatrick, J. W. (2004). Family Tyrannidae (Tyrant-flycatchers). In 'Handbook of the Birds of the World. Vol. 9: Cotingas to Pipits and Wagtails'. (Eds J. Del Hoyo, A. Elliott and D. A. Christie.) pp. 170-462. (Lynx Edicions: Barcelona.)

Gustafsson, L., and Sutherland, W. J. (1988). The costs of reproduction in the Collared Flycatcher Ficedula albicollis. Nature 335, 813-815. doi: $10.1038 / 335813 \mathrm{a} 0$

Hesse, R., Allee, W. C., and Schmidt, K. P. (1937). 'Ecological Animal Geography.' (Wiley: New York.)

Jahn, A. E., and Tuero, D. T. (2013). Fork-tailed Flycatcher (Tyrannus savana). In 'Neotropical Birds Online'. (Ed. T. S. Schulenberg.) (Cornell Lab of Ornithology: Ithaca, NY.) Available at http://neotropical.birds. 
cornell.edu/portal/species/overview?p_p_spp=482636 [Verified 21 July 2014]

Jahn, A. E., Levey, D. J., Mamani, A. M., Saldias, M., Alcoba, A., Ledezma, M. J., Flores, B., Vidoz, J. Q., and Hilarion, F. (2010). Seasonal differences in rainfall, food availability, and the foraging behavior of Tropical Kingbirds in the southern Amazon Basin. Journal of Field Ornithology 81, 340-348. doi:10.1111/j.1557-9263.2010.00290.x

Jahn, A. E., Levey, D. J., Cueto, V. R., Ledezma, J. P., Tuero, D. T., Fox, J. W., and Masson, D. (2013). Long-distance bird migration within South America revealed by light-level geolocators. Auk 130, 223-229. doi:10.1525/auk.2013.12077

Jetz, W., Sekercioglu, C. H., and Böhning-Gaese, K. (2008). The worldwide variation in avian clutch size across species and space. PLoS Biology $\mathbf{6}$, e303. doi:10.1371/journal.pbio.0060303

Lack, D. (1947). The significance of clutch-size. Ibis 89, 302-352. doi:10.1111/j.1474-919X.1947.tb04155.x

Lack, D. (1954). 'The Natural Regulation of Animal Numbers.' (Clarendon Press: Oxford, UK.)

Lima, S. L. (1987). Clutch size in birds: a predation perspective. Ecology 68 1062-1070. doi: $10.2307 / 1938378$

Lima, S. L. (2009). Predators and the breeding bird: behavioral and reproductive flexibility under the risk of predation. Biological Reviews of the Cambridge Philosophical Society 84, 485-513. doi:10.1111/j.1469185X.2009.00085.X

Marini, M. Â., Lobo, Y., Lopes, L. E., França, L. F., and Paiva, L. V. (2009). Biologia reprodutiva de Tyrannus savana (Aves, Tyrannidae) em cerrado do Brasil Central. Biota Neotropica 9, 55-63. doi:10.1590/S167606032009000100007

Martin, T. E. (1996). Life history evolution in tropical and south temperate birds: what do we really know? Journal of Avian Biology 27, 263-272. doi: $10.2307 / 3677257$

Martin, T. E., Martin, P. R., Olson, C. R., Heidinger, B. J., and Fontaine, J. J. (2000). Parental care and clutch sizes in North and South American birds. Science 287, 1482-1485. doi:10.1126/science.287.5457.1482

Mattsson, B. J., Latta, S. C., Cooper, R. J., and Mulvihill, R. S. (2011). Latitudinal variation in reproductive strategies by the migratory Lousiana Waterthrush. Condor 113, 412-418. doi:10.1525/cond.2011.090212

Mezquida, E. T. (2002). Nidificación de ocho especies de Tyrannidae en la Reserva de Ñacuñan, Mendoza, Argentina. Hornero 17, 31-40.

Mobley, J. M. (2013). Fork-tailed Flycatcher (Tyrannus savana). In 'Handbook of the Birds of the World Alive'. (Eds J. Del Hoyo, A. Elliott and D. A. Christie and E. de Juana.) (Lynx Edicions: Barcelona.) Available at http://www.hbw.com/node/57488 [Verified 21 July 2014].

R Core Team (2013). R: a language and environment for statistical computing. (R Foundation for Statistical Computing: Vienna, Austria.) Available at http://www.R-project.org [Verified 3 September 2014].

Restall, R., Rodner, C., and Lentino, M. (2006). 'Birds of Northern South America.' (Yale University Press: New Haven, CT.)

Ricklefs, R. E. (1970). Clutch size in birds: outcome of opposing predator and prey adaptations. Science 168, 599-600. doi:10.1126/science.168. 3931.599

Ricklefs, R. E. (1980). Geographical variation in clutch size among passerine birds: Ashmole's hypothesis. Auk 97, 38-49.
Ricklefs, R. E., and Wikelski, M. (2002). The physiology/life-history nexus. Trends in Ecology \& Evolution 17, 462-468. doi:10.1016/S0169-5347 (02)02578-8

Ridgely, R. S., and Tudor, G. (1994). 'The Birds of South America. Vol. II: The Suboscine Passerines.' (University of Texas Press: Austin, TX.)

Robinson, W. D., Robinson, T. R., Robinson, S. K., and Brawn, J. D. (2000). Nesting success of understory forest birds in central Panama. Journal of Avian Biology 31, 151-164. doi:10.1034/j.1600-048X.2000.310207.x

Robinson, W. D., Hau, M., Klasing, K. C., Wikelski, M., Brawn, J. D., Austin, S. H., Tarwater, C. E., and Ricklefs, R. E. (2010). Diversification of life histories in New World birds. Auk 127, 253-262. doi:10.1525/auk. 2010.127.2.253

Roff, D. A. (1992). 'The Evolution of Life Histories.' (Chapman and Hall: New York.)

Rose, A. P., and Lyon, B. E. (2013). Day length, reproductive effort, and the avian latitudinal clutch size gradient. Ecology 94, 1327-1337. doi: $10.1890 / 12-0953.1$

Salvador, S. A. (2013). Biology of the Fork-tailed Flycatcher (Tyrannus savana) in the Department General San Martín, Córdoba, Argentina. Histoire et Nature 3, 47-59.

Samaš, P., Grim, T., Hauber, M. E., Cassey, P., Weidinger, K., and Evans, K. L. (2013). Ecological predictors of reduced avian reproductive investment in the southern hemisphere. Ecography 36, 809-818. doi:10.1111/ j.1600-0587.2012.07927.x

Skutch, A. F. (1949). Do tropical birds rear as many young as they can nourish? Ibis 91, 430-455. doi:10.1111/j.1474-919X.1949.tb02293.x

Slagsvold, T. (1982). Clutch size variation in passerine birds: the nest predation hypothesis. Oecologia 54, 159-169. doi:10.1007/BF00378388

Snow, D. W. (1962). A field study of the Black and White Manakin, Manacus manacus, in Trinidad. Zoologica 47, 65-104.

Snow, D. W. (1978). The nest as a factor determining clutch-size in tropical birds. Journal of Ornithology 119, 227-230. doi:10.1007/ BF01644591

Stutchbury, B. J., and Roberston, R. J. (1988). Within-season and age-related patterns of reproductive performance in female Tree Swallows (Tachycineta bicolor). Canadian Journal of Zoology 66, 827-834. doi:10.1139/ z88-122

Teul, M., Piaskowski, V. D., and Williams, K. M. (2007). The breeding biology of the Fork-tailed Flycatcher (Tyrannus savana) in lowland pine savanna habitats in Belize. Ornitologia Neotropical 18, 47-59.

von Haartman, L. (1971). Population dynamics. In 'Avian Biology'. (Eds D. S. Farmer and J. R. King.) pp. 391-459. (Academic Press: New York.)

Winkler, D. W., and Allen, P. E. (1996). The seasonal decline in Tree Swallow clutch size: physiological constraint or strategic adjustment? Ecology 77, 922-932. doi:10.2307/2265512

Yom-Tov, Y., Christie, M. I., and Iglesias, G. J. (1994). Clutch size in passerines of southern South America. Condor 96, 170-177. doi: $10.2307 / 1369074$

Zanette, L. Y., Hobson, K. A., Clinchy, M., Travers, M., and Williams, T. D. (2013). Food use is affected by the experience of nest predation: implications for indirect predator effects on clutch size. Oecologia 172, 1031-1039. doi:10.1007/s00442-012-2570-y 